\title{
Pengembangan Sumber Daya Akademik Pada Universitas Sintuwu Maroso Kabupaten Poso.
}

\author{
Sepryanus, Rano Putra,M.Pd
}

\begin{abstract}
Sepryanus, Rano Putra, 2011. The Development of Academic Human Resources at University Sintuwu Maroso, Poso Regency.
\end{abstract}

This study aimed to analyze and describe: (1) the development of lectures at Universitas Sintuwu Maroso, (2) Supportive factors of development of lecturers at Universitas Sintuwu Maroso, (3) Inhibitive factors of the development of lecturers at Universitas Sintuwu Maroso, and (4) Effort to overcome the inhibitive factors of the development of lecturers at University Sintuwu Maroso.

The method used in this study was qualitative study. Technique of data gathering were as follows: (1) observation, (2) interviews, (3) document study. The instrument of this study was the researchers who equipped himself with an interview guide, field notes, tape recorder, and photo camera.

The results of the study were as follows:

1. The development of academic human resources was formulated in the plan of lecturers development which oriented in the outcomes expected for 5 years, name from 2010 to 2015; the plan was implemented through trainings and education.

2. In the process of academic human resources development, the researcher concluded that external and internal factors that supported the process of the development. The external factors were, among others, the Government's Rule No.14 Year 2005 which enforced the university lecturers development by meeting the qualification of the lectures education; and the scholarship for lectures who pursued their graduate studies by BPPS DIKTI. Internal factor was the support of the university management to realize this by giving financial aid for the initial education of the lecturers who pursued their graduate studies.

3. The inhibitive factors of the academic human resources development were the university's inadequate development fund and the lecturers difficulty to get the scholarship of BPPS DIKTI.

4. The efforts the university made to overcome the constraining factor of the academic human resources development were (a) the university's continuous coordination with the local Regional Government so as to give more special care for the university in order to support the development process of academic human resources, (b) the university's continuous effort to search for other sources of fund by planning to establish business units, and (c) the university's lecturers continuously gave direction and motivation in the management of the lecturers administrative matters, for instance, for their academic rank raise

Based on the findings of this study, it is recommended the following:

1. The academic human resources development of the lecturers at Universitas Sintuwu Maroso should be implemented by complete plan of human resources development by considering the needs of the lecturers. 
2. The lecturers should prepare early the administrative requirements which are important for their academic development process.

3. Universitas Sintuwu Maroso should work together with other prominent universities in the country and aboard so as to strengthen the relation and learn from them about the development of academic human resources.

4. Universitas Sintuwu Maroso should work together with institutions that provide the funds for the lecturers scholarship.

5. Similar studies should be conducted with broader scope.

\begin{abstract}
ABSTRAK
Sepryanus Rano Putra, 2011, Pengembangan Sumber Daya Akademik Pada Universitas Sintuwu Maroso Kabupaten Poso.
\end{abstract}

Penelitian ini bertujuan untuk mengkaji dan mendiskripsikan: (1) bagaimana pengembangan tenaga dosen pada Universitas Sintuwu Maroso, (2) faktor-faktor apakah yang menjadi pendukung dalam pengembangan tenaga dosen pada Universitas Sintuwu Maroso, (3) Faktor-faktor apakah yang menjadi penghambat terhadap pengembangan tenaga dosen pada Universitas Sintuwu Maroso, Upayaupaya apakah yang telah dilaksanakan untuk mengatasi faktor-faktor penghambat terhadap pengembangan tenaga dosen pada Universitas Sintuwu Maroso.

Metode yang digunakan dalam penelitian ini adalah metode penelitan kualitatif. Teknik pengumpulan data yang digunakan adalah: (1) observasi, (2) wawancara, (3) studi dokumentasi. Instrument penelitian adalah peneliti sendiri dengan menggunakan pedoman wawancara, catatan lapangan, tape recoder, dan kamera foto.

Hasil Penelitian sebagai berikut:

1. Pengembangan sumber daya akademik telah direncanakan melalui Rencana Pengembangan Dosen yang berorientasi pada hasil yang ingin dicapai selama kurun waktu 5 tahun 2010 sampai 2015 adapun tindakan nyata yang telah dilaksanakan yaitu melalui proses pendidikan dan pelatihan.

2. Dalam proses pengembangan tenaga akademik peneliti menyimpulkan bahwa ada faktor eksteren dan interen yang mendukung proses pengembangannya, faktor eksterennya antara lain yaitu dengan dikeluarkannya Undang-Undang No.14 Tahun 2005 oleh pemerintah sehingga mau tidak mau mengharuskan pihak Universitas untuk melakukan pengembangan tenaga dosennya dalam hal ini untuk memenuhi kualifikasi pendidikan para dosen, hal ini juga didukung dengan adanya beasiswa bagi para dosen yang akan melanjutkan studinya melalui BPPS DIKTI, faktor interennya adalah adanya dukungan dari pihak Universitas untuk mewujudkan hal ini yaitu dengan memberikan bantuan biaya awal pendidikan bagi dosen yang akan melanjutkan studinya.

3. Selain hal positif ada pula faktor-faktor penghambat yang menjadi kendala terhadap pengembangan sumber daya akademik pada Universitas Sintuwu Maroso, antara lain yang menjadi faktor utama menurut peneliti adalah masalah minimnya dana yang dimiliki oleh Universitas dalam proses pengembangan faktor penghambat lainnya adalah sulitnya bagi para dosen untuk bisa mendapatkan bantuan beasiswa BPPS DIKTI.

4. Adapun upaya-upaya yang dilakukan oleh pihak Universitas dalam mengatasi faktor penghambat tersebut adalah dengan terus mengadakan koordinasi dengan Pemerintah Daerah setempat agar dapat lebih memperhatikan Universitas secara khusus dalam menunjang proses pengembangan sumber daya akademik yang ada, selain pihak Universitas terus berupaya dalam mendapatkan sumber-sumber dana lainnya yang akan dilakukan melalui unit-unit usaha 
yang rencananya akan dikembangkan oleh Universitas, bagi para dosen pihak Universitas terus memberikan pengarahan dan motivasi secara khusus dalam pengurusan hal-hal administratif dosen seperti pengurusan pangkat akademik dan lain sebagainya.

Berdasarkan temuan-temuan penelitian tersebut diatas, maka disarankan sebagai berikut:

1. Pengembangan SDM dalam hal ini tenaga akademik pada Universitas Sintuwu Maroso dilakukan dengan perencanaan SDM yang matang dimana pengembangan yang dilakukan harus selalu memperhatikan kebutuhan para dosen yang ada.

2. Pihak Universitas lebih banyak lagi memberikan pendidikan dan pelatihan bagi tenaga akademiknya khususnya pendidikan dan pelatihan yang bertujuan untuk pengembangan profesi tenaga dosen

3. Para tenaga dosen sedini mungkin harus mempersiapkan hal-hal administratif yang dianggap penting bagi proses pengembangan tenaga akademik.

4. Agar dalam pengembangan sumber daya akademik pada Universitas Sintuwu Maroso para dosen tidak hanya terfokus hanya pada program S2 di Universitas-Universitas tertentu saja melainkan menyebar keseluruh Universitas yang ada di Indonesia agar kesempatan untuk memperoleh beasiswa lebih besar.

5. Dilakukan koordinasi dengan Pemerintah Daerah Kabupaten Poso sehingga dapat dihasilkan solusi yang tepat dalam proses Pengembangan Universitas Sintuwu Maroso

6. Pihak Universitas memanfaatkan segala sumber daya yang ada pada Universitas Sintuwu Maroso untuk dapat dijadikan sebagai unit usaha yang dapat menghasilkan sumber-sumber dana tambahan sehingga kedepan Universitas Sintuwu Maroso dapat menjadi Universitas yang mandiri.

7. Agar dilaksanakan penelitian sejenis yang berskala luas di kemudian hari. 


\section{PENDAHULUAN}

\section{A. Latar Belakang}

Dalam suatu organisasi pengembangan sumber daya manusia merupakan faktor utama dan mutlak perlu diperhatikan bagi kinerja organisasi, karena itu pimpinan selaku pengelola organisasi hendaknya secara profesional harus memiliki kemampuan untuk merencanakan, mengorganisasikan, mengarahkan dan mengendalikan kegiatan organisasi. Oleh sebab itu perlulah ada bagian sumber daya manusia yang dapat membantu pimpinan untuk menjalankan strategi organisasi.

Menurut Simamora (2006:273) pengembangan diartikan sebagai "penyiapan individu untuk memikul tanggungjawab yang berbeda atau yang lebih tinggi di dalam organisasi. Pengembangan biasanya berhubungan dengan peningkatan kemampuan intelektual atau emosional yang diperlukan untuk menunaikan pekerjaan yang baik".

Universitas Sintuwu Maroso Kabupaten Poso, merupakan salah satu perguruan tinggi di Indonesia yang berperan penting dalam menghasilkan manusia yang cerdas, terampil dan berakhlak di kabupaten Poso, diharapkan memliki SDM yang memadai dan profesional dalam menghadapi era perkembangan teknologi, reformasi dan globalisasi yang sedang terjadi saat ini, sejalan dengan beriringnya waktu tentunya ada banyak kendala yang dihadapi oleh Universitas Sintuwu Maroso khususnya bagi sumber daya manusia. Namun sebagai suatu organisasi kependidikan yang memiliki sumber daya manusia yang besar maka sangat dibutuhkan kemampuan pimpinan Universitas dalam perencanaan dan pengembangan sumber daya manusia secara khusus bagi tenaga dosen.

Berkaitan dengan uraian tersebut di atas, peneliti merasa tertarik untuk meneliti “ Pengembangan Sumber Daya Akademik pada Universitas Sintuwu Maroso Kabupaten Poso".

\section{B. Fokus Penelitian}

Berdasarkan kajian latar belakang permasalahan di atas yang telah diuraikan di atas, maka penelitian ini difokuskan pada "Pengembangan Sumber Daya Akademik khususnya tenaga dosen pada Universitas Sintuwu Maroso Kabupaten Poso".

\section{Rumusan Masalah}

Sesuai fokus penelitian di atas, maka rumusan masalah adalah sebagai berikut:

1. Bagaimana pengembangan tenaga dosen pada Universitas Sintuwu Maroso, Poso ?

2. Faktor-faktor apakah yang menjadi pendukung dalam pengembangan tenaga dosen pada Universitas Sintuwu Maroso, Poso ?

3. Faktor-faktor apakah yang menjadi penghambat terhadap pengembangan tenaga dosen pada Universitas Sintuwu Maroso, Poso ?

4. Upaya-upaya apakah yang telah dilaksanakan untuk mengatasi faktor penghambat terhadap pengembangan tenaga dosen pada Universitas Sintuwu Maroso, Poso ?

\section{Tujuan Penelitian}

Berdasarkan rumusan masalah di atas, maka tujuan penelitian ini adalah untuk memperoleh deskripsi yang jelas dan rinci tentang:

1. Pengembangan tenaga dosen pada Universitas Sintuwu Maroso, Kabupaten Poso

2. Faktor-faktor yang menjadi pendukung dalam pengembangan tenaga dosen pada Universitas Sintuwu Maroso, Kabupaten Poso.

3. Faktor-faktor yang menjadi penghambat terhadap pengembangan tenaga dosen pada Universitas Sintuwu Maroso, Kabupaten Poso.

4. Upaya-upaya yang telah dilaksanakan untuk mengatasi faktor penghambat terhadap pengembangan tenaga dosen pada Universitas Sintuwu Maroso, Kabupaten Poso. 


\section{E. Manfaat Penelitian}

Penelitian ini diharapkan memberikan manfaat secara praktis dan teoretis sebagai berikut:

1. Manfaat Teoretis

Secara teori, hasil penelitian ini diharapkan dapat bermanfaat bagi pengembangan ilmu manajemen pendidikan pada umumnya dan khususnya bagi pelaksanaan manajemen sumber daya manusia yang profesional sehingga dapat meningkatkan kinerja staf khususnya bagi tenaga dosen.

2. Manfaat Praktis

a. Penelitian ini diharapkan dapat bermanfaat bagi pelaksanaan manajemen sumber daya manusia pada Universitas Sintuwu Maroso Kabupaten Poso.

b. Penelitian ini diharapkan pula dapat memberikan manfaat praktis bagi elemen stakeholder pendidikan bahwa pelaksanaan manajemen sumber daya manusia dalam rangka menigkatkan kinerja dan profesionalisme kerja adalah sangat penting bagi para dosen dalam rangka meningkatkan mutu pendidikan.

\section{ACUAN TEORI}

\section{A. Konsep Manajemen Sumber Daya Manusia}

Manajemen pada dasarnya dibutuhkan oleh seluruh organisasi, karena tanpa manajemen, semua usaha ataupun kegiatan untuk mencapai suatu tujuan akan sia-sia. Hani Handoko (2007:26-27) mengemukakan tiga alasan utama diperlukannya manajemen, yakni: (1) untuk mencapai tujuan, (2) untuk menjaga keseimbangan di antara tujuan-tujuan yang saling bertentangan, (3) untuk mencapai efisiensi dan efektifitas.

Pemahaman manajemen menurut beberapa ahli dapat dikemukakan sebagai berikut:

Menurut Terry (dalam Kambey,2006:1) "Manajemen adalah pencapaian sesuatu tujuan yang telah ditentukan sebelumnya melalui usaha-usaha orang lain". Sedangkan Fathoni Abdulrahman (2006:5) berpendapat "Hakikat manajemen adalah proses pemberian bimbingan, pimpinan, pengaturan, pengendalian, dan pemberian fasilitas lainnya". Selanjutnya Follet (dalam T.Hani Handoko,2001:3) menjelaskan sebagai "Seni untuk menyelesaikan pekerjaan orang melalui orang lain".

Gomes (dalam Kambey,1999:4) membahas definisi Manajemen Sumber Daya Manusia dalam perspektif makro dan mikro. Dari segi makro mengemukakan bahwa Manajemen Sumber Daya Manusia adalah pengembangan dan pemanfaatan personil atau pegawai bagi pencapaian yang efektif mengenai sasaran-sasaran dan tujuan-tujuan individu,organisasi,masyarakat nasional dan internasional, sedangkan dari segi mikro dijelaskan bahwa manajemen sumber daya manusia adalah penarikan, seleksi, pengembangan, penggunaan dan pemeliharaan sumber daya manusia oleh organisasi.

Sedangkan menurut Flippo dalam Handoko (2010:3), Manajemen Sumber Daya Manusia adalah perencanaan, pengorganisasian, pengarahan, dan pengawasan kegiatan-kegiatan pengadaan, pengembangan, pemberian kompensasi, pengintegrasian, pemeliharaan,dan pelepasan sumber daya manusia agar tercapai berbagai tujuan individu, organisasi, dan masyarakat.

Dari penjelasan diatas dapat disimpulkan bahwa manajemen sumber daya manusia mempunyai definisi sebagai suatu perencanaan, pengorganisasian, pengarahan, dan pengawasan atas pengadaan, pengembangan, kompensasi, pengintegrasian, pemeliharaan, dan pemutusan hubungan kerja dengan maksud untuk mencapai tujuan organisasi secara terpadu.

Setelah kita melihat pengertian Manajemen Sumber Daya Manusia adapun tujuan dari Manajemen Sumber Daya Manusia menurut pandangan beberapa ahli sebagai berikut: 
Menurut Susilo Martoyo (2000:13) tujuan manajemen SDM dapat dirinci menjadi empat tujuan utama yaitu: (1) tujuan organisasi, (2) tujuan fungsional, (3) tujuan sosial, (4) tujuan personal.

Menurut Cushway (dalam Sutrisno, 2010:7) tujuan Manajemen Sumber Daya Manusia meliputi:

1. Memberi pertimbangan manajemen dalam membuat kebijakan sumber daya manusia untuk memastikan bahwa organisasi memiliki pekerja yang bermotivasi dan berkinerja yang tinggi, memiliki pekerja yang selalu siap mengatasi perubahan dan memenuhi kewajiban pekerjaan secara legal.

2. Mengimplementasikan dan menjaga semua kebijakan dan prosedur sumber daya manusia yang memungkinkan organisasi mampu mencapai tujuannya.

3. Membantu dalam pengembangan arah keseluruhan organisasi dan strategi, khususnya yang berkaitan dengan implikasi sumber daya manusia.

4. Memberi dukungan dan kondisi yang membantu manajer lini dalam mencapai tujuannya.

5. Menangani berbagai krisis dan situasi sulit dalam hubungan antar pekerja untuk meyakinkan bahwa mereka tidak menghambat organisasi dalam mencapai tujuannya.

6. Menyediakan media komunikasi antara pekerja dan manajemen organisasi.

7. Bertindak sebagai pemelihara standar organisasional dan nilai dalam manajemen sumber daya manusia.

\section{Pengertian Pengembangan Sumber Daya Manusia}

Adapun beberapa pengertian pengembangan menurut beberapa ahli seperti dibawah ini: Menurut Siagian (2009:183)

- Pengembangan adalah peningkatan produktivitas kerja para pekerja di masa depan.

- Peningkatan kemampuan melaksanakan tugas baru di masa depan.

- Pengembangan merupakan investasi sumber daya manusia untuk jangka panjang.

Selain itu Ambar Teguh Sulistiyanti dan Rosidah (2009:176) menjelaskan "Pengembangan adalah mewakili suatu investasi yang berorientasi ke masa depan dalam diri pegawai".

Dari beberapa pendapat di atas maka dapatlah disimpulkan bahwa pengembangan merupakan proses peningkatan keterampilan teknis, teoritis, konseptual, dan moral pegawai melalui pendidikan dan pelatihan. Pendidikan dan pelatihan yang diberikan hendaknya sesuai dengan kebutuhan pekerjaan masa kini maupun masa yang akan datang.

\section{Faktor-faktor yang mempengaruhi Pengembangan Sumber Daya Manusia}

Pengembangan sumber daya manusia secara makro adalah penting dalam rangka mencapai tujuan-tujuan pembangunan secara efektif. Pengembangan sumber daya manusia yang terarah dan terencana disertai pengelolaan yang baik akan dapat menghemat sumber daya alam, atau setidak-tidaknya pengelolahan dan pemakaian sumber daya alam dapat secara berdaya guna dan berhasil guna. Demikian pula pengembangan sumber daya manusia secara mikro di suatu organisasi sangat penting dalam mencapai hasil kerja yang optimal. Baik secara makro maupun secara mikro pengembangan sumber daya manusia adalah merupakan bentuk investasi .

Dapat disimpulkan bahwa proses pengembangan sumber daya manusia adalah suatu "condition sine qua non" yang harus ada dan terjadi di suatu organisasi. Namun demikian dalam pelaksanaan pengembangan sumber daya manusia ini perlu mempertimbangkan berbagai faktor, baik dari dalam diri organisasi itu sendiri maupun dari luar organisasi yang bersangkutan (internal maupun eksternal).

a. Faktor Internal 
Faktor internal di sini mencakup keseluruhan kehidupan organisasi yang dapat dikendalikan baik oleh pimpinan maupun oleh anggota organisasi yang bersangkutan. Secara terinci faktor-faktor tersebut antara lain:

1). Visi

Visi adalah impian, cita-cita atau harapan yang ingin dicapai oleh organisasi tersebut dalam kurun waktu tertentu. Visi adalah merupakan petunjuk kemana organisasi tersebut akan diarahkan.

2). Misi

Misi adalah upaya-upaya untuk mewujudkan visi atau impian suatu organisasi. Upayaupaya organisasi dalam mencapai cita-cita organisasinya sangat tergantung dari sumber daya manusia dari organisasi yang bersangkutan. Uapaya-upaya organisasi dalam mencapai visi ini diwujudkan dalam bentuk program-program pokok.

3). Tujuan

Tujuan adalah apa yang ingin dicapai setiap upaya atau program organisasi. Untuk mencapai tujuan ini diperlukan perencanaan yang baik, serta implementasi perencanaan tersebut secara tepat. Pelaksanaan kegiatan atau program organisasi dalam rangka mencapai tujuan ini diperlukan kemampuan sumber daya manusia, dan ini hanya dapat dicapai dengan pengembangan sumber daya manusia dalam organisasi tersebut.

4). Strategi pencapaian tujuan

Misi dan tujuan suatu organisasi mungkin mempunyai persamaan dengan organisasi lain, tetapi strategi untuk mencapai misi dan tujuan tersebut berbeda. Oleh sebab itu setiap organisasi mempunyai strategi yang tertentu. Untuk itu diperlukan kemampuan karyawannya dalam memperkirakan dan mengantisipasi keadaan di luar yang dapat mempunyai dampak terhadap organisasi.

5). Sifat dan jenis kegiatan

Sifat dan jenis kegiatan organisasi sangat penting pengaruhnya terhadap pengembangan sumber daya manusia dalam organisasi yang bersangkutan. Suatu organisasi yang sebagian melaksanakan kegiatan teknis, maka pola pengembangan sumber daya manusia akan berbeda dengan organisasi yang bersifat alamiah misalnya. Demikian pula strategi dan program pengembangan sumber daya manusia akan berbeda antara organisasi yang kegiatannya rutin dengan organisasi yang kegiatannya memerlukan inovasi dan kreatif.

6). Jenis teknologi yang digunakan

Sudah tidak asing lagi bahwa setiap organisasi dewasa ini telah menggunakan teknologi yang bermacam-macam dari yang paling sederhana sampai dengan yang paling canggih. Hal ini perlu diperhitungkan dalam program pengembangan sumber daya manusia dalam organisasi. Pengembangan sumber daya manusia disini diperlukan, baik untuk mempersiapkan tenaga guna menangani atau mengoperasikan teknologi itu, atau mungkin terjadinya otomatisasi kegiatan-kegiatan yang semula dilakukan oleh manusia.

\section{b. Faktor Eksternal}

Suatu organisasi berada di dalam lingkungan tertentu, dan tidak terlepas dari pengaruh lingkungan di mana organisasi itu berada. Agar organisasi itu dapat melaksanakan visi, misi, dan tujuannya, maka ia harus memperhitungkan faktor-faktor lingkungan atau faktor-faktor eksternal organisasi itu. Faktor-faktor eksternal tersebut antara lain:

\section{1). Kebijaksanaan Pemerintah}

Keebijaksanaan-kebijaksanaan pemerintah, baik yang dikeluarkan melalui perundangundangan, peraturan-peraturan pemerintah, surat-surat keputusan mentri atau pejabat pemerintah, dan sebagainya adalah merupakan arahan yang harus diperhitungkan oleh suatu 
organisasi. Kebijaksanaan-kebijaksanaan tersebut sudah barang tentu mempengaruhi program-program pengembangan sumber daya manusia dalam organisasi yang bersangkutan.

2). Sosio-budaya masyarakat

Faktor sosio-budaya masyarakat tidak dapat diabaikan suatu organisasi. Hal ini dapat dipahami karena suatu organisasi apapun didirikan untuk kepentingan masyarakat yang mempunyai latar belakang sosio-budaya yang berbeda-beda. Oleh sebab itu dalam pengembangan sumber daya manusia dalam suatu organisasi faktor sosio budaya ini perlu dipertimbangkan.

3). Perkembangan ilmu pengetahuan dan teknologi

Perkembangan ilmu pengetahuan dan teknologi di luar organisasi dewasa ini telah sedemikian pesatnya. Sudah barang tentu suatu organisasi yang baik harus mengikuti arus tersebut. Untuk itu maka organisasi harus mampu untuk memilih teknologi yang tepat untuk organisasinya. Untuk itu kemampuan karyawan organisasi harus diadaptasikan dengan kondisi tersebut.

\section{Manajemen Tenaga Pendidik dan Kependidikan}

Tenaga pendidik dan kependidikan dalam proses pendidikan memegang peranan strategis terutama dalam upaya membentuk watak bangsa melalui pengembangan kepribadian dan nilai-nilai yang diinginkan. Dipandang dari dimensi pembelajaran, peranan pendidik (guru, dosen, pamong pelajar, instruktur, tutor, widyaswara) dalam masyarakat Indonesia tetap dominan sekalipun teknologi yang dapat dimanfaatkan dalam proses pembelajaran berkembang aman dan cepat. Hal ini disebabkan karena ada dimensi-dimensi proses pendidikan, atau lebih khusus lagi pembelajaran, yang diperankan oleh pendidik yang tidak dapat digantikan oleh teknologi. Fungsi mereka tidak akan bisa seluruhnya dihilangkan sebagai pendidik dan pengajar bagi peserta didiknya, begitupun dengan tenaga kependidikan (kepala sekolah, pengawas, tenaga perpustakaan, tenaga administrasi) mereka bertugas melaksanakan administrasi, pengelolaan, pengembangan, pengawasan, dan pelayanan teknis untuk menunjang proses pendidikan pada satuan pendidikan.

Sehubungan dengan tuntutan kearah profesionalisme tenaga pendidik dan kependidikan, maka semakin dirasakannya desakan untuk peningkatan mutu pendidikan pada setiap jenis dan jenjang pendidikan yang telah menjadi komitmen pendidikan nasional. Isu klasik yang selalu muncul selama ini ialah : usaha apa yang paling tepat untuk meningkatkan mutu pendidikan melalui peningkatan mutu pendidik dan tenaga kependidikan. Oleh karenanya penting untuk memahami terlebih dahulu bagaimana mengelola pendidik dan kependidikan tersebut.

\section{a. Definisi Tenaga Pendidik dan Kependidikan}

Menurut Undang-undang No 20 tahun 2003 tentang Sistem Pendidikan Nasional pasal 1 ayat 5 dan 6 yang di maksud dengan tenaga Kependidikan adalah anggota masyarakat yang mengabdikan diri dan di angkat untuk menunjang penyelenggaraan pendidikan. Sedangkan pendidik adalah tenaga kependidikan yang berkualifikasi sebagi guru, dosen, konselor, pamong belajar, widyaiswara, tutor, instruktur, fasilitator, dan sebutan lain yang sesuai dengan kekhususannya, serta berpartisipasi dalam menyelenggarakan pendidikan.

\section{b. Definisi Manajemen Tenaga Pendidik dan Kependidikan}

Dalam organisasi pendidikan tenaga pendidik dan kependidikan ini merupakan sumber daya manusia potensial yang turut berperan dalam mewujudkan tujuan pendidikan nasional.

Berdasarkan asumsi ini, penulis mengacu pada beberapa teori tentang manajemen sumber daya manusia pada organisasi swasta/perusahaan yang sebelumnya sudah diuraikan diatas, maka dari pengertian tersebut maka dapat ditarik kesimpulan bahwa manajemen tenaga pendidik dan kependidikan adalah aktivitas yang harus dilakukan mulai dari tenaga 
pendidik dan kependidikan itu masuk ke dalam organisasi pendidikan sampai akhirnya berhenti melalui proses perencanaan sumber daya manusia, perekrutan, seleksi, penempatan, pemberian kompensasi, penghargaan, pendidikan dan latihan dan pemberhentian.

c. Tujuan Manajemen Tenaga Pendidik dan Kependidikan

Tujuan manajemen tenaga pendidik dan kependidikan berbeda dengan manajemen sumber daya manusia pada konteks bisnis, di dunia pendidikan tujuan manajemen sumber daya manusia lebih mengarah pada pembangunan pendidikan yang bermutu, membentuk sumber daya manusia yang handal, produktif, kreatif dan berprestasi.

Di negara kita ada satu Direktorat Tenaga Pendidik di bawah Dirjen Peningkatan Mutu Pendidik dan Kependidikan (PMPTK) yang memiliki wewenang untuk mengatur, mengelolatenaga pendidik dan kependidikan.

Berdasarkan (Permendiknas No.8 Tahun 2005) Tugas Ditjen PMPTK Direktorat Jendral Peningkatan Mutu Pendidik dan Tenaga Kependidikan mempunyai tugas merumuskan serta melaksanakan kebijakan standarisasi teknis di bidang peningktan mutu pendidik dan tenaga kependidikan pendidikan usia dini, pendidikan dasar, pendidikan menengah, dan pendidikan non formal

Adapun fungsi Ditjen PMPTK adalah sebagai berikut:

1) Penyiapan perumusan kebijakan departemen di bidang peningkatan mutu pendidik dan tenaga kependidikan.

2) Pelaksanaan kebijakan di bidang peningkatan mutu pendidik dan tenaga kependidikan.

3) Penyusunan standar, norma, pedoman, kriteria, dan prosedur dibidang peningkatan mutu pendidik dan tenaga kependidikan.

4) Pemberian bimbingan teknis dan evaluasi di bidang peningkatan mutu pendidik dan tenaga kependidikan.

5) Pelaksanaan urusan administrasi Direktorat Jenderal.

Penjabaran tugas dan fungsi dari Ditjen PMPTK ini merupakan tujuan yang ingin dicapai dalam manajemen tenaga pendidik dan kependidikan. Aas Syefudin (dalam Tim dosen administrasi pendidikan Universitas Pendidikan Indonesia 2009:232) menyebutkan bahwa tujuan pengelolaan tenaga pendidik dan kependidikan adalah agar mereka memiliki kemampuan, motivasi dan kreativitas untuk:

1) Mewujudkan sistem sekolah yang mampu mengatasi kelemahan-kelemahannya sendiri.

2) Secara berkesinambungan menyesuaikan program pendidikan sekolah terhadap kebutuhan kehidupan (belajar) peserta didik dan persaingan terhadap kehidupan masyarakat secara sehat dan dinamis.

3) Menyediakan bentuk kepemimpinan yang mampu mewujudkan human organization yang pengertiannya lebih dari human relationship pada setiap jenjang manajemen organisasi pendidikan nasional.

Dari uraian-uraian tersebut penulis menarik kesimpulan bahwa tujuan manajemen tenaga pendidik dan kependidikan secara umum adalah :

a) Memungkinkan organisasi mendapatkan dan mempertahankan tenaga kerja yang cakap, dapat dipercaya dan memiliki motivasi tinggi.

b) Meningkatkan dan memperbaiki kapasitas yang dimiliki oleh karyawan.

c) Mengembangkan sistem kerja dengan kinerja tinggi yang meliputi prosedur perekrutan dan seleksi yang ketat, sistem kompensasi dan insentif yang disesuaikan dengan kinerja, pengembangan manajemen serta aktivitas pelatihan yang terkait dengan kebutuhan organisasi dan individu.

d) Mengembangkan praktik manajemen dengan komitmen tinggi yang menyadari bahwa tenaga pendidik dan kependidikan merupakan stakeholder internal yang berharga serta membantu mengembangkan iklim kerjasama dan kepercayaan bersama. 
e) Menciptakan iklim kerja yang harmonis.

d. Tugas dan Fungsi Tenaga Pendidik dan Kependidikan

Berdasarkan Undang-undang No. 20 tahun 2003 Pasal 39 : (1) Tenaga kependidikan bertugas melaksanakan administrasi, pengelolaan, pengembangan, pengawasan, dan pelayanan teknis untuk menunjang proses pendidikan pada satuan pendidikan. (2) Pendidik merupakan tenaga profesional yang bertugas merencanakan dan melaksanakan proses pembelajaran, menilai hasil pembelajaran, melakukan pembimbingan dan pelatihan, serta penelitian dan pengabdian kepada masyarakat, terutama pendidik pada perguruan tinggi.

Secara khusus tugas dan fungsi tenaga pendidik (guru dan dosen) didasarkan pada Undang-undang No.14 Tahun 2007, yaitu sebagai agen pembelajaran untuk meningkatkan mutu pendidikan nasional, pengembangan ilmu pengetahuan, teknologi dan seni, serta pengabdi kepada masyarakat. Dalam pasal 6 disebutkan bahwa: Kedudukan guru dan dosen sebagai tenaga profesional bertujuan untuk melaksanakan sistem pendidikan nasional dan mewujudkan tujuan pendidikan nasional, yaitu berkembangnya potensi peserta didik agar menjadi manusia yang beriman dan bertakwa kepada Tuhan Yang Maha Esa, berakhlak mulia, sehat, berilmu, cakap, kreatif, mandiri, serta menjadi warga negara yang demokratis dan bertanggung jawab.

Dalam menjalankan tugas dan fungsinya secara profesional tenga pendidik dan kependidikan harus memiliki kompetensi yang diisyaratkan baik oleh peraturan pemerintah maupun kebutuhan masyarakat antara lain:

a. Pendidik harus memiliki kualifikasi minimum dan sertifikasi sesuai dengan jenjang kewenangan mengajar, sehat jasmani dan rohani, serta memiliki kemampuan untuk mewujudkan tujuan pendidikan nasional.

b. Pendidik untuk pendidikan formal pada jenjang pendidikan usia dini, pendidikan dasar, pendidikan menengah, dan pendidikan tinggi dihasilkan oleh perguruan tinggi yang terakreditasi.

\section{Pengembangan Akademik Pada Perguruan Tinggi}

Pengembangan program akademik merupakan upaya sistematis dan berencana yang dilakukan perguruan tinggi dalam rangka menata dan memperteguh peran dan fungsi sebagai lembaga pendidikan tinggi. Tuntutan terhadap peran perguruan tinggi dalam kehidupan berbangsa dan bernegara tidak pernah berhenti, karena bangsa yang cerdas dan bermartabat adalah bangsa yang ditata oleh ilmu pengetahuan, teknologi maupun seni.

Kedudukan dan peran strategis yang diemban perguruan tinggi, mengharuskan lembaga ini secara terus menerus melakukan perubahan dan perbaikan dalam rangka peningkatan mutu perguruan tinggi. Oleh karena itu, pengembangan akademik merupakan salah satu langkah penting bagi perguruan tinggi dalam rangka memperkuat jati diri sebagai agen pembaruan masyarakat.

Menurut Syahrizal (2009:146) pengembangan akademik dapat dilakukan melalui upaya penguatan kapasitas dosen/karyawan, pemanfaatan pendanaan, kapasitas mahasiswa, dan stakeholders lainnya. Adapun kegiatan yang dimaksud adalah:

a) Dosen dan Karyawan

- Memberikan kesempatan seluas-luasnya bagi dosen dan karyawan untuk meningkatkan kualitasnya.

- Memberikan gaji dan tunjangan yang memadai dan cukup.

- Memberikan pengangkatan jenjang karir yang jelas.

- Memperkuat penelitian.

- Meningkatkan fasilitas riset. 
- Membuat kebijakan yang senantiasa membuat dosen dan karyawan lebih menyenangkan.

- Mengundang dosen asing atau dosen berprestasi diluar lembaganya.

- Meningkatkan wawasan dosen dengan cara mengundang dan memperbanyak kuliahkuliah utama, seminar ilmiah,penataran dan kegiatan ilmiah yang lain.

- Meningkatkan dan menerbitkan karya-karya ilmiah dosen, baik melalui jalur ilmiah, buku atau lainnya.

b) Pendanaan

- Diperlukan pendanaan yang cukup baik untuk pembangunan fasilitas pendidikan yang baru maupun untuk pemeliharaan gedung dan fasilitas kampus yang lama.

- Diperlukan pendanaan yang cukup untuk operasional perguruan tinggi baik untuk gaji dan insentif, maupun biaya administrasi dan lain-lain.

c) Mahasiswa

- Menerima mahasiswa baru harus hanya dari mereka yang mempunyai kualitas sehingga tidak dijumpai angka putus kuliah.

- Membina mahasiswa sedemikian rupa sehingga membantu meningkatkan nilai tambah pendidikan dan seterusnya mampu membantu terwujudnya kemampuan kompetisi bagi perguruan tinggi tersebut.

d) Stakeholders lainnya

- Memanfaatkan stakeholder lain untuk membantu perguruan tinggi dalam meningkatkan mutu dan kompetisi. Misalnya dengan memanfaatkan peran alumni, donator dan anggota masyarakat lainnya.

\section{METODOLOGI PENELITIAN}

\section{A. Pendekatan Penelitian}

Pendekatan yang akan dipergunakan dalam penelitian ini adalah dengan menggunakan pendekatan kualitatif. Pendekatan kualitatif merupakan suatu paradigma penelitian untuk mendeskripsikan peristiwa, perilaku orang atau suatu keadaan pada tempat tertentu secara rinci dan mendalam dalam bentuk narasi.

\section{B. Tempat dan Waktu Penelitian}

\section{Tempat Penelitian}

Penelitian ini akan dilaksanakan pada Universitas Sintuwu Maroso Kabupaten Poso, Provinsi Sulawesi Tengah. Penetapan ini didasarkan pada pertimbangan bahwa lokasi penelitian mudah dijangkau dari tempat tinggal peneliti. Dengan demikian berdasarkan alasan di atas, lokasi penelitian ini ditentukan sendiri oleh peneliti yang dilakukan secara proporsional karena peneliti bekerja dan berdomisili di daerah tersebut, sehingga dapat mempermudah untuk memperoleh data yang akurat di lokasi penelitian, juga mempertimbangkan efisiensi serta apakah terdapat kesesuaian dengan kenyataan yang berada di lapangan, keterbatasan geografis dan praktis dalam pemanfaatan waktu, biaya, dan tenaga.

\section{Data dan Sumber Data}

\section{Data}

Penjaringan data dalam penelitian ini berhubungan erat dengan fokus permasalahan yang diteliti, yakni berhubungan dengan pengembangan manajemen sumber daya akademik pada Universitas Sintuwu Maroso Kabupaten Poso yang meliputi :

a) Pelaksanaan pengembangan sumber daya akademik.

b) Faktor-faktor pendukung dalam pelaksanaan pengembangan sumber daya dosen.

c) Faktor-faktor penghambat dalam pelaksanaan pengembangan sumber daya dosen. 
d) Upaya-upaya yang telah dilaksanakan untuk mengatasi faktor penghambat terhadap pengembangan tenaga dosen.

Menurut Moleong (2005:157) "karakteristik dari data utama adalah dalam bentuk katakata atau ucapan dari orang-orang yang diamati atau di wawancarai, sedangkan data pendukung atau tambahan adalah dalam bentuk dokumen-dokumen". Dengan demikian terdapat dua jenis data yang terkumpul dalam penelitian ini yaitu data utama yang diperoleh dari informan kunci dan hasil wawancara lainnya, sedangkan data pendukung diperoleh dari dokumen-dokumen berupa catatan lapangan, arsip dokumen-dokumen, gambar/foto.

\section{Sumber Data}

Yang akan menjadi sumber data utama dalam penelitian ini adalah yang disebut informan, peristiwa, dokumen melalui observasi situasi yang wajar sebagaimana adanya tanpa dipengaruhi dengan sengaja. Sumber data dalam penelitian ini kemudian dituangkan dalam catatan lapangan. Catatan lapangan yang dimaksud adalah kumpulan segala informasi yang berkaitan dengan masalah penelitian yang dilakukan peneliti sewaktu pengamatan lapangan, sedangkan wawancara langsung adalah kegiatan penggalian data yang dilakukan peneliti secara langsung dari informan.

\section{Teknik Pengumpulan Data}

Prosedur pengumpulan data dalam penelitian ini menggunakan pengumpulan data yaitu:

1. Observasi Partisipasi (Participant Observation)

Peneliti melakukan observasi unuk memperoleh data lengkap dan rinci melalui pengamatan saksama dengan melibatkan diri dalam kegiatan subjek yang sedang diteliti.

2. Wawancara Mendalam (In Dept Interview)

Teknik wawancara mendalam digunakan peneliti untuk menggali dan menghimpun informasi sebanyak-banyaknya dari informan sehingga data yang diperoleh akurat dan dapat dipertanggungjawabkan.

3. Dokumentasi

Teknik ini digunakan untuk menggali dan menghimpun data melaui informasi dari arsiparsip dokumen, catatan dan rekaman dalam memferifikasi data sekaligus sebagai kesimpulan dari data observasi dan wawancara.

\section{PEMBAHASAN}

Berdasarkan temuan penelitian ini maka berikut ini akan diuraikan pembahasan temuantemuan tersebut dikaitkan dengan justifikasi teoretik yang relevan.

1. Bagaimana pengembangan tenaga dosen pada Universitas Sintuwu Maroso Kabupaten Poso?

Pengembangan sumber daya akademik pada Universitas Sintuwu Maroso dilaksanakan berdasarkan rencana pengembangan dosen yang dibuat oleh universitas dimana berorientasi pada hasil yang ingin dicapai selama kurun waktu 5 tahun yaitu 2010 sampai 2014 adapun tindakan nyata yang telah dilaksanakan yaitu di mulai pada saat rekruitmen dosen, pada saat ini para calon dosen diberikan pelatihan-pelatihan yang menunjang perkembangan karirnya sebagai tenaga pengajar nantinya, selain itu pihak universitas juga memberikan dorongan dan perhatian bagi pengembangan pendidikan khususnya bagi dosen-dosen yang masih bergelar S1, dorongan ini diberikan kepada dosen-dosen agar mereka dapat melanjutkan studinya ke jenjang yang lebih tinggi, hal ini juga didukung dengan adanya program beasiswa dari DIKTI yang dapat memungkinkan para dosen untuk dapat melanjutkan studinya. Selanjutnya pengembangan dilakukan melalui pelatihan-pelatihan baik di tingkat universitas yang dilaksanakan oleh kopertis dan juga pelatihan-pelatihan yang bersifat interen fakultas masingmasing. 
Kegiatan pengembangan mengarah pada perubahan keahlian, pengetahuan, sikap atau perilaku. Aktivitas-aktivitas pengembangan baik pendidikan dan pelatihan adalah program organisasional yang terencana, dan penting bahwa aktivitas tersebut direncanakan secermat mungkin karena tujuan akhirnya adalah untuk peningkatan kemampuan sumber daya manusia dalam perilaku kerja yang dikehendaki.

Selanjutnya pengertian pengembangan, menurut Simamora (2006:273) yaitu "penyiapan individu untuk memikul tanggungjawab yang berbeda atau yang lebih tinggi di dalam organisasi". Pengembangan biasanya berhubungan dengan peningkatan kemampuan intelektual atau emosional yang diperlukan untuk menunaikan pekerjaan yang lebih baik bagi staf dan berfokus pada kebutuhan umum jangka panjang organisasi, yang mana hasilnya bersifat tidak langsung dan hanya diukur dalam jangka panjang. Pengembangan juga membantu para staf untuk mempersiapkan diri menghadapi perubahan dalam pekerjaan mereka yang dapat diakibatkan oleh perubahan-perubahan yang terjadi pada masa tertentu. Sesuai tujuan pengembangan sumber daya akademik ini, maka Universitas Sintuwu Maroso sebagai suatu organisasi pendidikan perlu dan sangat penting menyiapkan tenaga akademiknya agar dalam organisasi akan tersedia tenaga-tenaga pengajar yang profesional dibidangnya masing-masing.

2. Faktor-faktor apakah yang menjadi pendukung dalam pengembangan tenaga dosen pada Universitas Sintuwu Maroso, Poso ?

Pengembangan tenaga dosen pada Universitas Sintuwu Maroso terlebih khusus bagi pengembangan pendidikan para tenaga akademik tidak lepas dari peran serta pemerintah yang turut mendukung pengembangan tenaga dosen, ini terlihat dari dikeluarkannya Undangundang No.14 Tahun 2005 secara khusus pada Pasal 46 ayat 1 dan 2 yang berbunyi demikian:

(1) Kualifikasi akademik dosen sebagaimana dimaksud dalam Pasal 45 diperoleh melalui pendidikan tinggi program pascasarjana yang terakreditasi sesuai dengan bidang keahlian.

(2) Dosen memiliki kualifikasi akademik minimum:

a. lulusan program magister untuk program diploma atau program sarjana; dan

b. lulusan program doktor untuk program pascasarjana.

Hal ini juga didukung dengan tindak nyata pemerintah dalam mewujudkan pengembangan tersebut yaitu dengan memberikan kesempatan bagi para dosen-dosen untuk memperoleh beasiswa untuk melanjutkan studi ke jenjang yang lebih tinggi sesuai dengan kualifikasi yang dimaksud diatas. Oleh sebab itu pihak Universitas Sintuwu Maroso dalam hal ini pimpinan Univerasitas menghimbau kepada para dosen-dosen untuk segera melanjutkan studinya bagi dosen-dosen secara khusus bagi dosen yang belum memenuhi kualifikasinya sebagai dosen, selain itu pihak Universitas Sintuwu Maroso juga memberikan dukungan bagi para dosen yang akan melanjutkan studinya yaitu dengan memberikan bantuan dana yang meskipun hanya terbatas tetapi diharapkan dapat meringankan beban biaya pendidikan bagi para dosen yang akan melanjutkan studinya.

3. Faktor-faktor apakah yang menjadi penghambat terhadap pengembangan tenaga dosen pada Universitas Sintuwu Maroso, Poso ?

Universitas Sintuwu Maroso merupakan perguruan tinggi yang didirikan oleh Pemerintah Kabupaten Poso dan sampai saat ini dikelola oleh Pemerintah Daerah melalui Yayasan Sintuwu Maroso, jadi Universitas Sintuwu Maroso adalah aset daerah Kabupaten Poso yang keberadaannya haruslah diperhatikan oleh Pemerintah Daerah. Namun pada kenyataannya saat ini Pemerintah Daerah kurang memperhatikan keberadaan Universitas ini hal ini terbukti dengan minimnya bantuan anggaran pendidikan yang dialokasikan kepada Universitas Sintuwu Maroso secara khusus bantuan bagi pengembangan sumber-sumber daya 
akademik yang ada di Universitas Sintuwu Maroso, sehingga membuat pihak Universitas terus berusaha mencari dananya sendiri. Inilah faktor penghambat utama yang peneliti dapatkan dalam penelitian ini. Selain faktor diatas ada penghambat lain yang didapatkan yaitu sulitnya bagi para dosen untuk memperoleh bantuan beasiswa dari Pemerintah dalam hal ini beasiswa dari Dikti hal ini terjadi karena untuk mendapatkan beasiswa tersebut dosen harus memenuhi berbagai pesyaratan antara lain adalah dosen harus memiliki pangkat akademik, masalahnya disini adalah banyak dosen-dosen yang belum mempunyai pangkat akademik sehingga itu juga yang merupakan hambatan bagi pengembangan dosen pada Universitas Sintuwu Maroso.

Menurut Hani Handoko (2010:15) "setiap organisasi dikelilingi oleh suatu lingkungan eksternal yang terdiri dari berbagai variable, variable-variabel yang sebagian besar tak dapat dikendalikan oleh sebab itu ada berbagai tantangan lingkungan eksternal yang dihadapi oleh manajemen personalia yaitu berbagai kondisi yang umum mencakup teknologi, peraturan pemerintah, sosial budaya, kondisi perekonomian, perubahan dalam pasar tenaga kerja, kondisi geografis, faktor-faktor demografis, dan kegiatan-kegiatan pesaing”. Demikian halnya dengan Universitas Sintuwu Maroso tidak lepas dari kendala-kendala yang merupakan penghambat dari perkembangannya, namun kiranya ini bisa menjadi pelajaran dan motivasi bagi pihak Universitas dalam menetapkan langkah-langkah yang tepat dalam proses pengembangan Universitas secara khusus bagi pengembangan sumber daya akademik yang ada didalamnya.

4. Upaya-upaya apa saja yang dilakukan oleh universitas dalam mengatasi faktor penghambat tersebut

Adapun upaya-upaya yang dilakukan oleh Universitas Sintuwu Maroso dalam mengatasi faktor-faktor penghambat dalam pengembangan sumber daya akademiknya yaitu antara lain dengan terus melakukan penjajakan kepada Pemerintah Daerah agar sekiranya dapat membantu Universitas dalam pengembangannya secara khusus pengembangan dosen-dosen yang ada di Unuversitas Sintuwu Maroso, selain itu pihak Universitas terus berupaya untuk mendapatkan sumber-sumber dana lainnya melalui unit-unit usaha yang rencananya akan dikembangkan oleh pihak Universitas diantaranya yaitu dengan memanfaatkan laboratoriumlaboratorium yang ada bagi proyek-proyek penelitian di daerah Kabupaten Poso. Khusus bagi para dosen selalu diberikan pengarahan dan motivasi agar dapat mempersiapkan diri guna pengembangan pendidikannya.

\section{KESIMPULAN DAN SARAN}

\section{A. Kesimpulan}

Berdasarkan analisis hasil penelitian sesuai dengan fokus penelitian tentang pengembangan sumber daya akademik pada Universitas Sintuwu Maroso Kabupaten Poso, diperoleh kesimpulan sebagai berikut:

1. Sebagai organisasi pendidikan, pengembangan sumber daya akademik khususnya bagi tenaga dosen pada Universitas Sintuwu Maroso telah dilakukan mulai pada saat rekrutmen tenaga dosen, pengembangan tersebut dilakukan melalui pelatihan-pelatihan yang diberikan kepada calon-calon tenaga dosen, pelatihan-pelatihan ini terus dilakukan secara intensif oleh pihak universitas dan juga oleh fakultas-fakultas masing-masing, selanjutnya pengembangan pendidikan dilakukan bagi para dosen-dosen yang masih bergelar S1 dimana mereka diberikan dukungan untuk dapat melanjutkan pendidikannya ke jenjang yang lebih tinggi hal ini juga tidak menutup kemungkinan bagi para dosen yang bergelar S2 untuk dapat melanjutkan studinya ke S3.

2. Adapun faktor pendukung dalam pengembangan sumber daya akademik pada Universitas Sintuwu Maroso antara lain adalah dengan dikeluarkannya peraturan pemerintah melalui 
Undang-undang No.14 tahun 2005 yang mengharuskan para dosen untuk memiliki spesifikasi pendidikan minimal S2 ini membuat para dosen di Universitas Sintuwu Maroso terus termotivasi untuk dapat melanjutkan studinya, selain itu pemerintah juga menyediakan beasiswa bagi para dosen-dosen yang akan melanjutkan studinya ke jenjang yang lebih tinggi melalui beasiswa BPPS DIKTI meskipun untuk bisa mendapatkannya tidak mudah namun ini sangat membantu para dosen untuk bisa melanjutkan studinya. Selain itu pihak universitas juga turut mendukung para dosen yang ingin melanjutkan studinya melalui pemberian bantuan biaya pendidikan bagi dosen yang akan melanjutkan studinya.

3. Selain faktor pendukung adapun faktor penghambat yang ditemui antara lain yaitu minimnya dana yang dimiliki oleh universitas sehingga proses pengembangan sumber daya akademik belum bisa tercapai dengan maksimal, hal lain yaitu kurangnya dukungan dari Pemerintah Daerah Kabupaten Poso dalam mengalokasikan anggaran pendidikan bagi Universitas Sintuwu Maroso padahal pemerintah daerah setempat melalui yayasan sintuwu maroso adalah pemilik dari pada universitas tersebut. Faktor penghambat yang lainnya adalah sulitnya bagi para dosen untuk mendapatkan bantuan beasiswa BPPS DIKTI hal ini dikarenakan masih banyak dosen yang belum dapat memenuhi segala persyaratan administratif yang diajukan oleh DIKTI.

4. Adapun upaya-upaya yang dilakukan untuk mengatasi faktor penghambat tersebut yaitu pihak universitas terus berupaya untuk mendapatkan sumber-sumber dana lainnya melalui unit-unit usaha yang rencananya akan dikembangkan oleh universitas, selain itu pihak universitas juga terus melakukan koordinasi dengan pemerintah daerah setempat agar kedepan dapat lebih memperhatikan pengembangan universitas secara khusus bagi pengembangan sumber daya akademik yang ada, bagi para dosen pihak universitas terus memberikan pengarahan dan motivasi secara khusus dalam pengurusan hal-hal administratif dosen seperti pengurusan pangkat akademik dan nomor induk dosen nasional atau NIDN.

\section{B. Saran}

Berdasarkan kesimpulan di atas demi kepentingan bersama dalam mengembangkan sumber daya akademik pada Universitas Sintuwu Maroso maka peneliti menyarankan:

1. Pengembangan sumber daya akademik dalam hal ini tenaga dosen pada Universitas Sintuwu Maroso dilakukan dengan perencanaan SDM yang matang dimana pengembangan yang dilakukan harus selalu memperhatikan kebutuhan para dosen yang ada.

2. Para dosen sedini mungkin harus mempersiapkan hal-hal administratif yang dianggap penting bagi proses pengembangan tenaga akademik.

3. Dalam pengembangan sumber daya akademik dalam hal ini pengembangan tenaga dosen Universitas Sintuwu Maroso sebaiknya menjalin kerjasama dengan universitas-universitas terkemuka lainnya di dalam baik di luar negeri agar pihak Universitas Sintuwu Maroso dapat lebih memperkuat relasi dan juga dapat saling belajar mengenai pengembangan sumber daya akademik.

4. Agar pihak Universitas Sintuwu Maroso mencari jaringan kerjasama dengan lembagalembaga penyandang dana pendidikan lainnya agar kedepan kesempatan beasiswa bagi para dosen lebih terbuka.

5. Agar dilaksanakan penelitian sejenis yang berskala luas di kemudian hari. 


\section{DAFTAR PUSTAKA}

Ambar Teguh Sulistiani \& Rosidah,2009.Manajemen Sumber Daya Manusia (Konsep,Teori,danPengembangan dalam Konteks Organisasi Publik), Yogyakarta, Graha Ilmu.

Abbas Syahrizal, 2009. Manajemen Perguruan Tinggi, Jakarta, Kencana.

Abdurrahman Fathoni, 2006. Organisasi dan Manajemen Sumber Daya Manusia,Jakarta, PT.Adimahastya.

Ghafur,Saha H, 2008. Manajemen Penjaminan Mutu Perguruan Tinggi di Indonesia, Jakarta, Bumi Aksara.

Hani,Handoko T, 2010. Manajemen Personalia dan Sumber Daya Manusia,Yogyakarta,BPFE.

Kambey, Daniel C. 1999. Manajemen Sumber Daya Manusia, Manado, Tri Ganesha Nusantara.

McKenna,Eugene \& Nic Beech, 1995. The Essence of Manajemen Sumber Daya Manusia (diterjemahkan oleh Totok Budi Santosa), Penerbit Andi bekerja sama dengan Pearson Education Asia Pte.Ltd.

Moleong,L, 2001. Metode penelitian Kualitatif, Bandung, Remaja Rosdakarya.

Nasution,S,1996. Metode Penelitian Naturalistik Kualitatif, Bandung, Tarsito.

Nasution,S,2009. Metode Research, Jakarta,Bumi Aksara.

Notoatmodjo,S, 2009. Pengembangan Sumber Daya Manusia, Jakarta, Rineka Cipta.

Sallis, Edward, 2008. Total Quality Management in Education (diterjemahkan oleh Ahmad Ali Riyadi \& Fahrurrozi), Jogjakarta. Ircisod.

Satori,D \& Komariah,A,2010. Metodologi Penelitian Kualitatif, Bandung, Alfabeta.

Sedarmayanti, 2009. Sumber Daya Manusia dan Produktivitas Kerja, Bandung, Mandar Maju.

Siagian,S, 2009. Manajemen Sumber Daya Manusia, Jakarta, Bumi aksara.

Sihotang, A, 2007. Manajemen Sumber Daya Manusia,Jakarta, PT.Pradnya Paramita.

Sudiyono,2004, Manajemen Pendidikan Tinggi, Jakarta, Rineka cipta.

Susilo Martoyo,2000. Manajemen Sumber Daya Manusia,Yokyakarta,BPFE.

Sutrisno,E, 2010. Manajemen Sumber daya Manusia, Jakarta, Kencana.

Tim Dosen UPI,2009. Manajemen Pendidikan, Bandung, Alfabeta. 
